\title{
Mucuna pruriens and its Effect on some Physical, Chemical and Biological Properties of a Forest Acrisol
}

\author{
S. Agyenim Boateng \\ CSIR-Soil Research Institute, Academy Post Office, Kwadaso-Kumasi, Ghana \\ Email:soils@africaonline.com.gh; sagyenimboateng@yahoo.com
}

\begin{abstract}
The effect of Mucuna pruriens, a herbaceous legume, on some properties of a forest acrisol was examined in RCBD experiment of four treatments: control, NPK fertilizer, mucuna incorporation and mucuna mulch. At flowering, the fresh biomass was cut at soil level, chopped up and applied to the soil either by incorporation or as mulch. In both cases, mucuna improved the physical, chemical and biological properties of the soil. Available soil moisture content increased from $9.54 \%$ to values between $10.20 \%$ and $11.40 \%$ while bulk density reduced from 1.42 to $1.36 \mathrm{Mg} \mathrm{m}^{-3}$. Total $\mathrm{N}$ increased from $0.14 \%$ to $0.18 \%$. Organic $\mathrm{C}$ and $\mathrm{K}$ levels did not change while $\mathrm{P}$ was slightly reduced. Earthworm populations in the mucuna plots were three times higher than those plots without mucuna. Mucuna suppressed weed growth. These improvements in the physical and chemical properties are indicators of the potential of $M$. pruriens in enhancing crop yields.
\end{abstract}

\section{Introduction}

The inherent low fertility status of soils in Ghana is a major contributing factor to low crop yield levels. Chemical fertilizers have been used to provide nutrients to crops in order to ensure sustainable yields. The limitation of chemical fertilizers on the physical conditions of the soil is of major concern, especially when viewed against the background of low organic matter levels of the soils in certain parts of the country.

With the increasing cost of these inputs emphasis is now shifted towards the use of biological management systems. Mucuna pruriens var. Utilis, a herbaceous legumi-nous crop, has been used as a cover crop and green manure elsewhere in Latin America, India and Asia. It is lately gaining popularity in Ghana. Although several reports have been made on its positive effect on crop yields (Fischler, 1996; Agyenim Boateng, 1997; van Noordwijk et al., 1995; Sanginga et al., 1996a), few data exist on its effect on the soil. Becker (unpublished; cited in Carsky et al., 1998) observed a 3-9\% increases in soil organic matter after a short mucuna fallow compared with a weedy fallow, although the difference was not statistically significant. After one season of mucuna, Carsky \&Tian (unpublished; also cited in Carsky et al.,1968) recorded 12\% higher total $\mathrm{N}$ compared to natural fallow at one site but no difference at another site. Nitrogen levels were slightly increased from $0.99 \%$ to values over $1 \%$ at Ejura in the forest savanna transition zone of Ghana when mucuna was incorporated or used as mulch (Agyenim Boateng, 1997).

Improvement in the physical and chemical properties of soil is an indication of a fertile soil which contributes immensely to the good performance of crop. The objective of the present study is to examine the effect of mucuna on some physical, chemical and biological properties of a Forest Acrisol in Ghana for sustainable agricultural production.

\section{Materials and methods}

Mucuna pruriens was grown on a Forest Acrisol (locally, Akroso series) at Kwadaso in the semi-deciduous rain forest zone of Ghana. The treatments were (i) control (i.e. without green manure or mineral fertilizer input), (ii) mineral fertilizer (i.e. 51-30-30 kg NPK/ha), (iii) mucuna incorporated and (iv) mucuna used as surface mulch (nonincorporation). The experiment was a randomized complete block design with four replications. Plot size per treatment was $50 \mathrm{~m}^{2}$.

Mucuna seeds were sown at $60 \mathrm{~cm}$ between rows $30 \mathrm{~cm}$ within rows. The crop was allowed to grow up to the flowering stage when it was cut, chopped up and placed on the soil surface as a mulch, and incorporated into the soil. Incorporation was done manually with the hoe. The mineral fertilizer consisted of four $50 \mathrm{~kg}$ bags of 15-15-15 NPK and two $50 \mathrm{~kg}$ bags of sulphate of ammonia per hectare. The soil was sampled for analysis before planting, at flowering, 4 weeks after mulching and incorporation, and 3 months after mulching and incorporation.

The following chemical analyses were carried out: (1) soil $p \mathrm{H}$ in water solution (1:2.5); (2) organic carbon by Walkley and Black wet combustion method; (3) total $\mathrm{N}$ by the macro-Kjedahl method; (4) available P by Bray P1 method and (5) exchangeable $\mathrm{K}, \mathrm{Ca}, \mathrm{Mg}$ and $\mathrm{Na}$ were extracted with $1.0 \mathrm{~N}$ neutral ammonium acetate solution. Potassium and $\mathrm{Na}$ were determined with the flame photometer, while $\mathrm{Ca}$ and $\mathrm{Mg}$ were determined by titration with EDTA solution. Exchangeable acidity ( $\mathrm{Al}$ and $\mathrm{H}$ ) was determined by the titration method after extraction with $1.0 \mathrm{~N}$ KCl. Effective cation capacity (ECEC) is the sum of $1.0 \mathrm{~N} \mathrm{NH}_{4} \mathrm{OAC}$ exchangeable bases plus $1.0 \mathrm{~N} \mathrm{KCl}$ exchangeable acidity.

Particle size analysis was determined by the Bouyoucos method. Bulk density of the soil was determined by the core method, and available moisture content (AMC) determined by using the formula,

$A M C=F C-P W P$

where FC is field capacity and PWP is permanent wilting point. 
Harvested plant samples of mucuna at flowering were taken and oven-dried at $70{ }^{\circ} \mathrm{C}$ for $48 \mathrm{~h}$ for biomass assessment and nutrient analysis following standard analytical methods. Weed count was done by using a 0.5-m quadrat. Nodulation was done by uprooting the plants, counting the number of nodules produced and cutting them open to examine effectiveness. An average of four plants was sampled. Earth-worm populations during the course of the study were enumerated.

\section{Characteristics of the soil}

\section{Results and discussion}

Initial soil properties of the experimental site are presented in Table 1. The mechanical analysis indicated that the soil was a sandy loam. Bulk density value $\left(1.42 \mathrm{Mg} \mathrm{m}^{-3}\right)$ was slightly high as is common to such tropical soils in the country with values between 1.35 and $1.4 \mathrm{Mg} \mathrm{m}^{-3}$. According to Young (1976), organic carbon value of $1.07 \%$ for the experimental site was low while total nitrogen and available phosphorus values of $0.14 \%$ and $17.85 \mathrm{mg} \mathrm{kg}^{-1}$, respectively, were moderate. The soil was extremely acidic, with a $p \mathrm{H}$ value of 4.7. Generally, the soil was low in exchangeable bases, with potassium value $\left(0.22 \mathrm{c} \mathrm{mol} \mathrm{kg}^{-1}\right)$ being moderate. Base saturation was, however, high (91\%).

TABLE 1

Some physical and chemical properties of the soil at the start of the experiment (top $0-20 \mathrm{~cm}$ )

\begin{tabular}{|c|c|c|}
\hline \multicolumn{2}{|l|}{ Parameter } & Description \\
\hline \multicolumn{2}{|l|}{$\mathrm{pH}\left(\mathrm{H}_{2} \mathrm{O}\right)$} & 4.7 \\
\hline \multicolumn{2}{|l|}{ Org. C (\%) } & 1.07 \\
\hline \multicolumn{2}{|l|}{ Org. matter (\%) } & 1.81 \\
\hline \multicolumn{2}{|l|}{ Total N (\%) } & 0.14 \\
\hline \multicolumn{2}{|l|}{ Available $\mathrm{P}\left(\mathrm{mg} \mathrm{kg}^{-1}\right)$} & 17.85 \\
\hline \multicolumn{2}{|l|}{ Aðvailable K (mg kg-1) } & 31.20 \\
\hline \multicolumn{3}{|c|}{ Exchangeable cations ( $\left.\mathrm{cmol} \mathrm{kg}^{-1}\right)$ : } \\
\hline \multicolumn{3}{|l|}{ К 0.22} \\
\hline \multicolumn{2}{|l|}{$\mathrm{Ca}$} & 2.32 \\
\hline \multicolumn{2}{|l|}{$\mathrm{Mg}$} & 0.56 \\
\hline \multicolumn{2}{|l|}{$\mathrm{Na}$} & 0.09 \\
\hline \multicolumn{2}{|l|}{$(\mathrm{Al}+\mathrm{H})$} & 0.30 \\
\hline \multicolumn{2}{|l|}{ ECEC $\left(\mathrm{cmol} \mathrm{kg}^{-1}\right)$} & 3.49 \\
\hline \multicolumn{2}{|l|}{ Base saturation (\%) } & 91 \\
\hline \multicolumn{3}{|l|}{ Particle size (\%): } \\
\hline Sand & 73.5 & \\
\hline Silt & 13.5 & \\
\hline Clay & 13.0 & \\
\hline Bulk density $\left(\mathrm{Mg} \mathrm{m}^{-3}\right)$ & 1.42 & \\
\hline Plant available water (\%) & 9.54 & \\
\hline
\end{tabular}

Characteristics of the mucuna plant

Some chemical and microbiological properties of the mucuna at the flowering stage when biological growth was at peak are presented in Table 2. Dry matter yield in the present study was higher than those reported by the following researchers: Muhr (1997), 4.8 t ha-1 $^{-1}$ Drechsel, Steiner \& Hagedorn (1996), 1.3-3.5 t ha ${ }^{-1}$ and Quintana (1987): 4.9 t ha $^{-1}$. Bowen (1987) and Fischler (1996) observed the same dry matter yield. However, Lathwell (1990), Klein (1994) and Sanginga et al. (1996a) noted higher yields of $6.7 \mathrm{t} \mathrm{ha}^{-1}, 7.4 \mathrm{t} \mathrm{ha}^{-1}$ and $7.7 \mathrm{t} \mathrm{ha}^{-1}$, respectively.

TABLE 2

Some properties of Mucuna pruriens var. utilis at flowering stage

Parameter

Description

Dry matter (t ha-1) 


$\begin{array}{lc}\text { Moisture content (\%) } & 74.2 \\ \text { Total nutrients (\%) } & 3.49 \\ \text { N } & 0.27 \\ \text { P } & 1.58 \\ \text { K } 1.76 & 0.38 \\ \text { Ca } & \\ \text { Mg } & \\ \text { Nodulation (per plant): } & 13 \\ \text { Total number } & 6 \\ \text { Number of effective nodules } & 0.9\end{array}$

Scanty data on nutrient composition of mucuna exist. Tian, Kang \& Brussard (1992) found 6\% N in mucuna leaves and petioles. Comparable figures have been reported from related leguminous green manure plants. Leucaena contains on a dry weight basis $3.0-3.5 \% \mathrm{~N}, 0.27 \% \mathrm{P}, 1.40 \% \mathrm{~K}$ and $0.80 \%$ Ca (Brewbaker \& Hilton, 1979). The number of nodules and effective ones per plant (13 and 6 respectively) is rather low compared with other legumes such as cowpea with over 50 nodules and canavalia with an average of 30.

In field experiments at four savanna sites, Sanginga et al. (1996b) found that nodule number at 16 weeks after planting (WAP) ranged from 3 to 27 per plant. However, the dry weight of effective nodules (0.9 g) per plant is consistent with what is reported in the literature. Inoculation with suitable strain is likely to improve the nodulation of the plant. Ladha, Miyan \& Garcia (1989), studying the effect of inoculation on nodulation found that Sesbania rostrata produced 17 nodules without inoculation and 78 nodules with inoculation.

Effect of mucuna pruriens on soil chemical properties

At flowering, the soils in the mucuna plots relative to the control suffered slight decreases of soil $p \mathrm{H}$, organic carbon, available $\mathrm{P}$ and available $\mathrm{K}$ levels except that of nitrogen. These decreases were probably due to crop uptake. The change of $16 \%$ in $\mathrm{N}$ may be ascribed to $\mathrm{N}$ fixation by mucuna. Carsky et al. (1998) reported that published estimates of the amounts of $\mathrm{N}$ derived from the atmosphere by mucuna ranged from less than 20 to more than 200 $\mathrm{kg} / \mathrm{ha}$.

There were no significant changes in $p \mathrm{H} 4$ weeks after addition of mucuna biomass to the soil (Table 3). Organic matter decreased with incorporation of mucuna but increased when mucuna was surface-applied. This decrease may be due to tillage during incorporation as a result of enhanced oxidation of organic matter leading to its rapid decomposition and loss (Agboola, 1990). Non-incorporation (without tillage), i.e. mucuna mulch, added some amount of organic matter from the decomposing mucuna residues. However, nitrogen levels increased over $20 \%$ when mucuna was incorporated as green manure. Non-incorporation maintained the nitrogen level. This observation is important since green manure legumes are used largely to increase nitrogen and soil organic matter (Agboola \& Fayemi, 1972; Allison, 1973; Quintana, 1987).

TABLE 3

Some chemical properties of the soil at flowering and 4 WAA of mucuna stages of the experiment $(0-20 \mathrm{~cm})^{*}$

\begin{tabular}{|c|c|c|c|c|c|c|}
\hline Time of sampling & $\begin{array}{l}\text { Soil pH } \\
\mathrm{H}\left(\mathrm{H}_{2} \mathrm{O}\right)\end{array}$ & Organic C \% & $\begin{array}{l}\text { Organic } \\
\text { matter \% }\end{array}$ & Total No.\% & $\begin{array}{l}\text { Available } \\
P \mathrm{mg} \mathrm{kg}^{-1}\end{array}$ & $K m g k^{-1}$ \\
\hline \multicolumn{7}{|l|}{ At flowering: } \\
\hline Control & $4.6(4.7)$ & $0.80(1.07)$ & $1.38(1.81)$ & $0.12(0.14)$ & 8.65(17.85) & $28.00(31.20)$ \\
\hline Mucuna plots & 4.7 & 0.82 & 1.42 & 0.14 & 13.45 & 30.20 \\
\hline
\end{tabular}

At four weeks after mucuna

application:

$\begin{array}{lrrrrrr}\text { Control } & 4.8 & 0.82 & 1.41 & 0.11 & 11.80 & 31.20 \\ 51-30-30 \text { kg NPK ha-1 }^{-1} & 4.6 & 0.86 & 1.48 & 0.14 & 21.45 & 15.60 \\ \text { Mucuna incorporation } & 4.7 & 0.78 & 1.34 & 0.18 & 8.95 & 30.60 \\ \text { Mucuna used as mulch } & 4.6 & 0.90 & 1.55 & 0.13 & 10.00 & 31.20\end{array}$

*Values were from bulked samples of treatments

Initial values in parentheses

WAA - weeks after application 
Available phosphorus and potassium did not show any appreciable increase for mucuna incorporation from the initial levels. It may be that $\mathrm{P}$ and $\mathrm{K}$ mineralization was still taking place. Similarly, non-incorporation did not greatly improve $\mathrm{P}$ and $\mathrm{K}$ levels (although they were slightly higher than incorporation).

At 3 months after mucuna application to the soil (Table 4), $p H$ levels did not change much. Organic matter levels dropped further from the previous levels by 0.18 units in the non-incorporated and 0.05 units in the incorporated plots. The falls might be explained by the fact that mucuna residues decompose rapidly so that by the end of the 3 months period most of the materials had decomposed, especially for the mulch plots. Tian, Kang \& Brussard (1992) observed mucuna decomposition rate to be among the highest in the leaves and petioles in a group of 10 herbaceous and woody species. It would, therefore, not be expected to contribute substantially to increasing soil organic matter content.

TABLE 4

Effect of Mucuna pruriens on chemical properties of the soil*

\begin{tabular}{|c|c|c|c|c|c|c|c|c|c|}
\hline \multirow[t]{3}{*}{ Treatment } & \multirow{3}{*}{$\begin{array}{l}\mathrm{pH} \\
\left(\mathrm{H}_{2} \mathrm{O}\right)\end{array}$} & \multirow[t]{3}{*}{ Org.C } & \multirow{3}{*}{$\begin{array}{l}\text { Org. } \\
\text { Matter }\end{array}$} & \multirow[t]{3}{*}{ Total N } & \multirow{2}{*}{\multicolumn{2}{|c|}{ Exchangeable cations }} & \multirow{3}{*}{ T.E.B ${ }^{1}$} & \multirow[b]{2}{*}{ Ex.Acid } & \multirow[b]{2}{*}{ d ECEC } \\
\hline & & & & & $\mathrm{Ca}$ & & & & \\
\hline & & & & & $\mathrm{cmol} \mathrm{kg}{ }^{-1}-{ }^{-}$ & -------- & & $(\%)$ & $(\mathrm{mg} / \mathrm{kg})$ \\
\hline Control & $4.8(4.7)$ & $0.71(1.07)$ & $1.22(1.81)$ & $0.08(0.14)$ & $3.36(2.32)$ & $0.88(0.56)$ & $0.17(0.22)$ & 0.09 & 4.50 \\
\hline 51-30-30 kg NPK ha-1 & 4.6 & 0.75 & 1.29 & 0.10 & 2.64 & 0.24 & 0.13 & 0.09 & 3.10 \\
\hline Mucuna incorporation & 4.8 & 0.75 & 1.29 & 0.14 & 2.96 & 0.64 & 0.17 & 0.09 & 2.86 \\
\hline Mucuna mulch & 4.8 & 0.79 & 1.37 & 0.12 & 2.16 & 0.56 & 0.13 & 0.09 & 2.94 \\
\hline
\end{tabular}

*Values were from bulked samples of treatments

${ }^{1}$ T. E. B. - Total exchangeable bases

The mucuna plots had higher organic matter levels than the control. It would seem that the added biomass added some amount of organic matter to the soil, especially from the incorporation and, therefore, could reduce its rapid decline. Larger increases of organic matter levels are likely with more repeated applications of mucuna biomass to the soil as reported by Buanec \& Jacob (1981), Allison (1973), and Agboola \& Fayemi (1972).

Nitrogen levels decreased from $0.18 \%$ and $0.13 \%$ to $0.14 \%$ and $0.12 \%$ for incor-poration and mulched treatments, respectively, by the third month. This could be due to several factors including the loss by leaching and volatilisation. This level of nitrogen in the soil from the mucuna-treated plots after 3 months is appreciable since it exceeded the control by $75 \%$ and chemical fertilizer by $40 \%$.

Available phosphorus increased slightly from $8.95 \mathrm{mg} \mathrm{kg}^{-1}$ at 4 weeks after mucuna application to $18.95 \mathrm{mg} \mathrm{kg}^{-1}$ and $10.00 \mathrm{mg} \mathrm{kg}^{-1}$ to $14.00 \mathrm{mg} \mathrm{kg}^{-1}$ at the end of the 3 months period. The results confirm the findings of Agboola (1975) and Kahnt (1983) that legume green manures are known to increase phosphorus content of soils when cut and applied to the soil.

For the exchangeable bases no change was observed for sodium. Potassium levels decreased from 0.22 to $0.13 \mathrm{c}$ mol kg-1 for the mulched and $0.17 \mathrm{c} \mathrm{mol} \mathrm{kg}^{-1}$ for the incorporation. However, magnesium increased from 0.38 to 0.56 and $0.64 \mathrm{c} \mathrm{mol} \mathrm{kg}^{-1}$ while calcium levels increased from 2.32 to $2.96 \mathrm{c} \mathrm{mol} \mathrm{kg}{ }^{-1}$ when mucuna was incorporated but decreased to $2.16 \mathrm{c} \mathrm{mol} \mathrm{kg}{ }^{-1}$ when surface applied. According to Agboola (1975) carbon dioxide and organic acids released during decomposition of green manures may act on insoluble soil minerals thereby, releasing nutrients into the soil solution. No appreciable change in $p \mathrm{H}$ was observed. Changes in soil $p \mathrm{H}$ due to green manuring are complex and dependent on soil type and conditions (Meelu et al., 1994).

Effects of Mucuna pruriens on some physical properties of the soil

Mucuna improved the moisture content of the soil from $9.54 \%$ to between $10.20 \%$ and $11.40 \%$ (Table 5). This is consistent with the findings of several workers (e.g. Biswas, Roy \& Sahu, 1970; Kang, Grimme \& Lawson, 1985) demonstrating moisture retention in soils upon green manure addition. Moisture retention in non-incorporated mucuna plots was better than the incorporated plots. This was because the mulch material could better conserve soil moisture. 
TABLE 5

Effect of Mucuna pruriens on physical properties of the soil*

\begin{tabular}{lcc} 
Treatment & $\begin{array}{c}\text { Plant available water } \\
(\%)\end{array}$ & $\begin{array}{c}\text { Bulk density } \\
\left(\mathrm{Mg} \mathrm{m}^{-3}\right)\end{array}$ \\
\hline Control & $9.44(9.54)^{* *}$ & $1.43(1.42)^{* *}$ \\
NPK (Chemical fertilizer) & 9.21 & 1.44 \\
Mucuna incorporation & 10.20 & 1.36 \\
Mucuna mulch & 11.40 & 1.39
\end{tabular}

\footnotetext{
* Values were from bulked samples of treatments

( ) **Values at the beginning of the experiment
}

Bulk density was slightly reduced after application of mucuna. The effect was more pronounced when the manure was incorporated (from 1.42 to $1.36 \mathrm{Mg} \mathrm{m}^{-3}$ ). Organic matter exerts a favourable influence on soil conditions by lowering bulk density as reported by several authors including Darra, Jain \& Uzzaman (1968) who observe a decrease of bulk density from 1.46 to $1.36 \mathrm{Mg} \mathrm{m}^{-3}$ and Jiao, Gu \& Zhang (1986) who noted a change from 1.39 to $1.31 \mathrm{Mg} \mathrm{m}^{-3}$.

Effect of Mucuna pruriens on some biological properties of the soil

Mucuna pruriens has a high potential for controlling weeds, including some obnoxious ones like Imperata cylindrica (Table 6). Weed pressure, notably Chromolaena odorata and Imperata cylindrica, was highest on the control plots without mucuna. On the contrary, weed population on the mucuna plots was low. These results agree with the findings of several works on mucuna in relation to weed control. Akobundu \&Poku (1984) reported that within 19 weeks, mucuna could completely cover plots infested with Imperata cylindrica. Osei Bonsu, Asibuo \& Asafu-Agyei (1995) observed that spear grass (Imperata cylindrica) was almost absent on plots with mucuna. Mucuna grows and forms a dense canopy to shade undergrowths.

\section{TABLE 6}

Weed control effect of mucuna after 90 days of growth

\begin{tabular}{|c|c|c|c|c|c|c|c|c|}
\hline \multicolumn{9}{|c|}{ Weed species (No. $\mathrm{m}^{-2}$ ) } \\
\hline $\begin{array}{l}\text { Treatment } \\
\text { odorata }\end{array}$ & $\begin{array}{l}\text { Chromolaena } \\
\text { spp. }\end{array}$ & $\begin{array}{c}\text { Commelina } \\
\text { exaltata }\end{array}$ & $\begin{array}{l}\text { Roethboelia } \\
\text { conyzoides }\end{array}$ & $\begin{array}{l}\text { Ageratum } \\
\text { cylindrica }\end{array}$ & $\begin{array}{l}\text { Imperata } \\
\text { regrowth }\end{array}$ & Stump & Others & Total \\
\hline Control & 25 & 9 & 15 & 19 & 32 & 3 & 5 & 108 \\
\hline Mucuna (live) & 1 & 1 & 1 & - & 2 & 1 & 2 & 8 \\
\hline
\end{tabular}

The thick canopy of mucuna might have provided suitable temperature, good moisture regime and aeration conducive to the survival and breeding of earthworms (Table 7). According to Meelu et al. (1994) green manures, by providing energy and nutrients, encourage the growth and activity of desirable soil organisms (including earthworms) that play a key role in transforming and liberating plant nutrients in the soil. Plots with mucuna resulted in more earthworm populations than those without mucuna. This implied that the activity of earthworms in the soil increased with the addition of the legume resulting in increased aeration of the soil and its infiltration, formation of fine-textured soils and improvement of nutrient status of the soil. This increase in earthworm populations as a result of the presence of the legume is in agreement with the findings of several investigators of legume green manures (Kutte \& Mann, 1968; Darra, Jain \& Uzzaman, 1968; Yaacob \& Blair, 1984). 


\begin{tabular}{lcc}
\hline Treatment & $\begin{array}{c}\text { Population } \\
\left(\text { number } / \mathrm{m}^{2}\right)\end{array}$ & Fresh weight of worms $\left(\mathrm{g} / \mathrm{m}^{2}\right)$ \\
\hline Bare & 40 & 9.2 \\
Mucuna incorporation & 124 & 31.00 \\
Mucuna mulch & 136 & 39.44 \\
\hline
\end{tabular}

* Values were from bulked samples of treatments

\section{Conclusion}

Mucuna increased soil N levels by about $20 \%$. Maintenance of organic matter is likely if mucuna fallow is part of the fallow systems in the country. $M$. pruriens reduced bulk density by 0.06 units and increased available water content by between 0.75 and 1.95 units. Earthworm population tripled and weed growth suppressed. The fertility of the soil can be improved by the use of mucuna technology to ensure sustained crop yields. Further research is needed to identify ecozones where the mucuna technology is applicable.

\section{References}

Agboola A. A. (1975). Problems of improving soil fertility by the use of green manuring in the tropical farming system. FAO Soil Bull. 27: 145-164.

Agboola A. A. (1990). Organic matter and soil fertility management in the humid tropics of Africa. IBSRAM Proc. 10: $231-244$.

Agboola A. A. and Fayemi A. A. A. (1972). Effect of soil management on corn yield and soil nutrients in the rain forest zone of western Nigeria. Agron. J. 64 (5): 641-644.

Agyenim Boateng S. (1997). Effects of Mucuna pruriens green manure on soil fertility and crop yield. Proceedings of the 14th and 14th Annual General Meetings of the Soil Science Society of Ghana, Accra. pp. 59-64.

Akobundu I. O. and Poku J. A. (1984). Control of Imperata cylindrica. Ann. Rep. Ibadan, Nigeria: International Institute of Tropical Agriculture.

Allison F. E. (1973). Soil organic matter and its role in crop production. Dev. Soil Sci. 3. Amsterdam: Elsevier.

Biswas T. D., Roy M. R. and Sahu B. N. (1970). Effect of different sources of organic manures on the physical properties of the soil growing rice. J. Indian Soc.Soil Sci. 18: 233-242.

Bowen W. T. (1987). Estimating the nitrogen contribution of legumes to succeeding maize on oxisol in Brazil. (PhD Thesis.) Cornell University, Ithaca, N.Y.

Brewbaker J. and Hilton E. M. (1979). Leucaena: A versatile tropical legume. In New Agricultural Crops, pp. 207259. AAS Selected Symposia. Boulder, Colorado: Westview Press.

Buanec B. Le and Jacob B. (1981). Dix-sept ans de culture motorisee sur un bassin versant du centre Côte d'Ivoire. Agron. Trop, 36 (3): 203-211.

Carsky R. J., Tarawall S. A. Becker M., Chilkoye D., Tian G. and Sanginga N. (1998). Mucuna - herbaceous cover legume with potential for multiple uses. Resource and Crop Management Research Monograph No. 25, Nigeria: IITA. 52 pp.

Darra B. L., Jain S. V., and Uzzaman Q. (1968). The influence of different green manure crops on soil structure and wheat yield. Indian J. Agron. 13: 162-164.

Drechsel P., Steiner, K. G. and Hagedorn F. (1996). A review on the potential of improved fallows and green manure in Rwanda. Agrofor. Sys. 33: 109-136.

Fischler M. (1996). Research on green manures in Uganda: Results from experiments conducted in 1995. Report submitted to the Rockefeller Foundation, Nairobi, Kenya. 31 pp.

Jiao B., Gu, R. and Zhang X. (1986). Chinese green manure. Beijing, China: Publishing House of Agriculture.

Kahnt G. (1983). Grundungung 2. verb. Auflage. DLG-Verlag, Frankfrust/M. 146 pp.

Kang B. T., Grimme H. and Lawson T. L. (1985). Alley cropping, sequentially cropped maize and cowpea with Leucaena on a sandy soil in Nigeria. Pl. Soil 85: 267-27.

Klein H. D. (1994). Introduction des légumineuses dans la rotation céréale cotonier au Nord Cameroun: Gestion et Utilisation, CIRAD-EMVT, Maizon-Alfort, France. 189 pp. 
Kutte D. B. and Mann H. S. (1968). Effect of green manuring on physical, chemical and biological properties of the soil. Indian J. Agron. 13: 20-25.

Ladha J. K., Miyan S. and Garcia M. (1989). Sesbania ristrata green manure for lowland rice: growth, nitrogen fixation Azorhizobium spp. Inoculation and effects on succeeding crop yields and nitrogen balance. Biol. Fert. Soil 7: 191-197.

Lathwell D. J. (1990). Legume green manures: Principles for management based on recent research. Soil Management CRSP Bulletin No. 00-01, Raleigh, North Carolina: Soil Management Collaborative Research Support Program, NCSU. 30 pp.

Meelu O. P., Yadvinder-Singh and Bijay-Singh (1994). Green manuring for soil productivity improvement. Wld Soil Resour. Rep. Rome: FAO. 123 pp.

Muhr L. (1997). Potential of Forage Legumes on Fallow Land for Enhanced Forage Production and Soil Fertility in Crop-Livestock Farming Systems of Subhumid West Africa. (PhD Thesis.) University of Hohenheim, Germany.

Osei Bonsu P., Asibuo J. Y. and Asafu-Agyei J. N. (1995). Studies on mucuna (Mucuna pruriens var. Utilis) in Ghana. Paper presented at the SAFGRAD Regional Workshop on Technology Options and Transfer Systems for Food Grain Production in sub-Saharan Africa, Abidjan, Cote d'Ivoire.

Quintana J. O. (1987). Evaluation of two procedures for screening legume green manures as nitrogen sources to succeeding corn. (Ph.D Thesis.) Cornell University. Ithaca, N.Y.

Sanginga N., Ibewiro B., Houngnandan P., Vanlauwe B., Okogun J. A., Akobundu I. O. and Versteeg M. (1996a). Evaluation of symbiotic properties and nitrogen contribution of mucuna to maize grown in the derived savanna of West Africa. Pl. Soil 179: 119-129.

Sanginga N., Wirkom L. E., Okogun A., Akobundu I.O., Carsky R. J., and Tian, G. (1996b). Nodulation and estimation of symbiotic nitrogen fixation by herbaceous and shrub legumes in Guinea savanna in Nigeria. Biol. and Fert. Soil 23: 441-448.

Tian G., Kang B.T. and Brussard L. (1992). Effects of chemical composition on N, Ca, and Mg release during incubation of leaves from selected agroforestry and fallow plants. Biogeochem. 16: 103-119.

Van Noordwijk M., Sitompul S. M., Hairiah K., Listyarini E. and Syekfani M. (1995). Nitrogen supply from rotational or spatially zoned inclusion of leguminosae for sustainable maize production on an acid soil in Indonesia. In Plant Soil Interactions at Low pH. ( R. A. Date et al., ed.), pp. 779-784. The Netherlands: Kluwer.

Yaacob O. and Blair G. J. (1981). Effect of legume cropping and organic matter accumulation on the infiltration rate and structural stability of a granite soil under a simulated tropical environment. Pl. Soil 60 (1): 11-20.

Young A. (1976). Tropical soils and soil survey. Cambridge Univ. Press. 467 pp. 